\title{
Effect of pasteurization and storage on tetracycline levels in honey
}

\author{
Francisco Molino, Regina LÁzaro, Consuelo Pérez, Susana Bayarri, \\ Lourdes Corredera, Antonio Herrera

\begin{abstract}
Área de Nutrición y Bromatología, Facultad de Veterinaria, Universidad de Zaragoza, C/Miguel Servet 177, C.P. 50013 Zaragoza, Spain
\end{abstract}

Received 11 November 2009 - Revised 20 June 2010 - Accepted 2 July 2010

\section{INTRODUCTION}

The occurrence of residues of antibiotics in foodstuffs, arising from its veterinary use, represents a potential danger for consumers worldwide, and is related to the appearance of allergic reactions, development of bacterial resistances, modifications in intestinal flora, and possible mutagenic and/or carcinogenic power (Demoly and Romano 2005; Andersen et al. 2005).

In apiculture sanitation, the tetracyclines, antibiotics of wide spectrum that prevent the growth of bacteria by inhibition of protein synthesis, are shown to be effective in controlling American foulbrood disease (AFD) and European foulbrood disease. AFD, caused by the spore-forming Paenibacillus larvae, is the most widespread and destructive of the bee brood diseases. The spore stage is infectious to honeybees. Larvae up to 3 days old become infected by ingesting spores that are present in their food. Spores germinate in the gut of the larvae and the vegetative form of the bacteria begins to grow. Comb cells containing infected larvae are discolored, sunken, and have punc-

Corresponding author: R. Lázaro, rlazaro@unizar.es

Manuscript editor: Peter Rosenkranz tured capping; the dead larvae have a soft, sticky, and ropy consistency.

Moreover, tetracyclines can be sprayed directly to fruit trees or other plants to treat infection by Erwinia amylovara and Mycoplas$m a$ and used to control infection of seeds by Xanthomonas campestris. So, the contamination of the plant with high concentrations of antibiotic implies the risk of residues into hive products (Levy 1992).

Tetracyclines are not authorized for the treatment of honeybees in the EU, although some countries, based on the cascade system, include tetracyclines on the list of registered products. As an example, the use of oxytetracycline for the treatment of European foulbrood with the withdrawal period of at least 6 months is allowed in the UK (EMA/28057/2010). The cascade system allows the use of veterinary medicines for bees authorized in other countries. However, there are some obstacles for its application: cascade provisions are for exceptional use, a maximum residue level (MRL) is required for a substance to be used under the cascade, and it is also necessary to have an MRL in honey to allow for residue control (Committee on the Food Chain and Animal Health 2007; EMA/28057/2010).

However, it is certainly the case that tetracyclines are authorized for the treatment of honeybees in 
many third countries. This situation may potentially raise some problems with imports of honey into the EU.

No MRLs for tetracyclines have been established in honey (Regulation (EC) No 470/2009 and Regulation (EU) No 37/2010). In consequence, the presence of any detectable residues of tetracyclines in honey would mean that the honey cannot legally be commercialized in the EU. In other words, there is zero tolerance for the presence of tetracylcline residues in honey. In 2008, the European Committee for Medicinal Products for Veterinary Use, in response to the request from the European Commission, reconsidered its previous opinion regarding the establishment of maximum residue limits for oxytetracycline in honey and agreed to recommend the establishment of a provisional maximum residue limit for oxytetracycline in honey. However, this MRL has not been set in the Regulation (EU) (No 37/2010).

In the absence of an EU MRL for tetracycline in honey, the limit of quantification may be used as the action level (the concentration of residue in food that results in action being taken). In the case of prohibited substances, any confirmed residue will be reported as in excess of the action level.

Related to this aspect, the Food Standards Agency of the UK (FSA 2010) has sought opinion from the European Commission and other competent authorities in the UK regarding setting a suitable Action level for oxytetracycline (OTC) residues in honey. Three options have been discussed: $25 \mu \mathrm{g} / \mathrm{kg}$ according to the FSA risk assessment; $20 \mu \mathrm{g} / \mathrm{kg}$ as recommended by the Community Reference Laboratory for screening for tetracycline residues in honey; and not detectable (i.e., below limit of detection). It remains to be decided as to what would constitute an acceptable limit of detection.

In order to evaluate the human risk derived from the occurrence of residues of antibiotics in foodstuffs, the joint Food and Agriculture Organization (FAO)/World Health Organization (WHO) Expert Committee of Food Additives and Contaminants (JECFA), established in 1998 a group acceptable daily intake (ADI) of 0
$0.03 \mathrm{mg} / \mathrm{kg}$ body weight for oxytetracycline, tetracycline, and chlortetracycline. Therefore, it is important that analytical methods used in antibiotic residue control plans are as sensitive and reliable as possible in order to provide assurances that honey commercialized in the EU will comply with community rules.

In this context, there is a continuous need of reliable analytical methods to use in determining compliance with national regulations as well as international requirements. Many methods have been developed for the determination of tetracyclines (TCs) in honey: microbiological inhibition tests (Jinbo et al. 1992), rapid tests for antibiotic screening, Tetrasensor (Unisensor, Lieje, Belge; Reybroeck et al. 2007), and Biacore QFlex Kits (Biacore International SA, Neuchatel, Switzerland).

Besides single-class methods, multi-class methods using LC-MS/MS (Alfredsson et al. 2005; Huq et al. 2006; Hammel et al. 2008; López et al. 2008; Pancorbo et al. 2008), enzyme immunoassay (Heering et al. 1998; PastorNavarro et al. 2007; Jeon and Paeng 2008), spectrophotometry (Salinas et al. 1991), flowinjection chemiluminescence (Pena et al. 2000; Kaczmarek and Lis 2009), high-performance liquid chromatography (HPLC; Viñas et al. 2004; Guo-Hui et al. 2005; Li et al. 2008; Sun et al. 2009; Tayar et al. 2010), and capillary electrophoresis (Nakazawa et al. 1999) are also used for the analysis of TC residues in honey.

Several studies have shown the presence of tetracycline residues in honey. In Belgium, Reybroeck (2003) found 18\% of samples contaminated with tetracycline. In a study carried out in Spain by the National Association of Consumers and Users, 5\% of samples analyzed contained residues of tetracycline (OCU 2003). However, Pena et al. (2005) did not detect residues of oxytetracycline and tetracycline above detection limits $(50 \mu \mathrm{g} / \mathrm{kg})$ in Spanish and Portuguese honeys, nor Viñas et al. (2004) in Spain, detected levels of OTC, TC, chlortetracycline (CTC), and doxycycline (DC) above detection limits $(30 \mu \mathrm{g} / \mathrm{kg}$; Viñas et al. 2004). In other countries, like Japan, Jinbo et al. (1992) detected chlortetracycline 
and oxytetracycline (7\% of positive samples). Sabatini et al. (2003), in Italy, detected oxytetracycline and tetracycline in $4 \%$ of samples at levels up to $1.0 \mu \mathrm{g} / \mathrm{kg}$ and Jürgens (1981) in a study of Romanian, Spanish, and Mexican honeys detected tetracycline residues at levels of $1.5-5.1 \mu \mathrm{g} / \mathrm{kg}$ ( $6 \%$ positive samples).

Pasteurization and storage of honey represent two important steps of the commercial chain that could influence its quality. Pasteurization is usually applied to prevent fermentation or delay granulation. Honey can be stored at different times during processing and exposure in the market. Little information is available concerning the effect of pasteurization and storage conditions on tetracycline residues in honey. Recently, Tayar et al. (2010) evaluated the stability of the tetracyclines during 60 days of storage in commercial honey samples. The residue levels of OTC, TC, and CTC were reduced $97 \%, 76 \%$, and $71 \%$, respectively.

In relation with the effect of storage conditions, Argauer and Moats (1991) reported a high percentage of oxytetracycline decrease $(50 \%)$ in honey stored at $34^{\circ} \mathrm{C}$. Similar results are reported by Matsuka and Nakamura (1990) in honey stored at $35^{\circ} \mathrm{C}$ and $25^{\circ} \mathrm{C}$.

Analytical methods to determine residues of tetracyclines in honey have been published and validated. None of them are official, which may be due to the complexity of the analysis of these contaminants in a complicated matrix such us honey.

The aim of this study was to determine the contamination of honey samples by the tetracyclines OTC, TC, CTC, and DC after pasteurization and under different storage conditions by using a reliable analytical method based on solid phase extraction (SPE) and HPLC.

\section{MATERIALS AND METHODS}

\subsection{Materials and reagents}

Analytical standard-grade of tetraciclyne $\left(\mathrm{C}_{22} \mathrm{H}_{25} \mathrm{ClN}_{2} \mathrm{O}_{8}\right)$, chlortetracycline $\left(\mathrm{C}_{22} \mathrm{H}_{24} \mathrm{Cl}_{2} \mathrm{~N}_{2} \mathrm{O}_{8}\right)$, oxytetracycline $\left(\mathrm{C}_{22} \mathrm{H}_{25} \mathrm{ClN}_{2} \mathrm{O}_{9}\right)$, and doxycycline $\left(\mathrm{C}_{22} \mathrm{H}_{24} \mathrm{~N}_{2} \mathrm{O}_{8} \mathrm{HCl} \cdot 0,5 \mathrm{H}_{2} \mathrm{O} \cdot 0,5 \mathrm{CH}_{3} \mathrm{CH}_{2} \mathrm{OH}\right)$ standards were purchased from Vetranal (Riedel-de Haën, Germany). Standards were dissolved in $\mathrm{pH} 3$ acetonitrile/oxalic acid $(15: 85 ; v / v)$. HPLC analysis grade ethyl acetate, acetonitrile, and methanol were provided by Labscan (Dublin, Ireland). Oxalic acid $\left((\mathrm{COOH})_{2} \cdot 2 \mathrm{H}_{2} \mathrm{O}\right)$ was supplied by Panreac Química S.A. (Barcelona, Spain). EDTA $\left(\mathrm{C}_{10} \mathrm{H}_{14} \mathrm{~N}_{2} \mathrm{Na}_{2} \mathrm{O}_{8} \cdot 2 \mathrm{H}_{2} \mathrm{O}\right), \mathrm{Na}_{2}$ EDTAMcllvaine buffer ( $\mathrm{pH} 4)$, sodium phosphate dibasic $\left(\mathrm{Na}_{2} \mathrm{HPO}_{4}\right)$, and citric acid $\left(\mathrm{C}_{6} \mathrm{H}_{8} \mathrm{O}_{7} \cdot \mathrm{H}_{2} \mathrm{O}\right)$ of analytical standard grade were from Panreac Química S.A. (Barcelona, Spain). Ultrapure water was prepared using a Milli-Q water purification system (Bedford, MA, USA). For solid-phase extraction, $\mathrm{C}_{18}$ (EC) $6 \mathrm{~mL}$ cartridges containing 0.5 and $1 \mathrm{~g}$ of octadecylsilica and $0.5 \mathrm{~g}$ of phenyl were from Isolute (International Sorbent Technology, Hengoed, UK). Ultrapure nitrogen $\mathrm{C}_{55}$ was supplied by Carburos Metálicos (Barcelona, Spain).

\subsection{Apparatus}

An analytical balance CP 224 S Sartorius (Goettingen, Germany), Temperature Bath Tectron $\mathrm{P}$ Selecta (Barcelona, Spain), Tembloc oven P Selecta (Barcelona, Spain), Vibratory stirrer TK3S Techno Kartell (Milan, Italy), MS2 Minishaker IKA (Staufen, Germany), and pH meter Crison GLP 21 (Barcelona, Spain) were used for preparation of samples. An SPE vacuum manifold for solid-phase extraction was supplied by Supelco (Bellefonte, USA). HPLC was performed on a Hewlett-Packard 1100 apparatus from Agilent (Karlsruhe, Germany) with a $20 \mu \mathrm{L}$ loop and a photodiode array detector (DAD). The injection was manual and a chromatographic column ACE $\mathrm{C}_{18}$ $(250 \times 4.1 \mathrm{~mm}$ I.D. $\times 5 \mu \mathrm{m}$; Advanced Chromatography Technologies, Aberdeen, UK) was used.

\subsection{TC evolution study}

Changes in tetracycline residue levels in spiked honeys were studied in two different experiments: after laboratory pasteurization $\left(78^{\circ} \mathrm{C} / 1 \mathrm{~min}\right.$ ) and during storage (room temperature/darkness at 30, 90, and 180 days).

\subsubsection{Samples}

Eleven raw Spanish multifloral honeys, with rosemary as the major component, were used for the study. Honey samples were directly provided by 
beekeepers, and analyzed in our laboratory to ensure that none contained tetracycline residues.

Two hundred fifty grams were collected from each sample of raw honey and settled into a glass pot with a metal screw. Each sample was spiked with $1 \mathrm{~mL}$ of an acetonitrile-oxalic acid (15:85) solution of oxytetracycline, tetracycline, chlortetracycline, and doxycycline of $125 \mu \mathrm{g} / \mathrm{mL}$. The final TC level in the samples was checked (487-494 ng/g honey).

\subsubsection{Pasteurization study}

Samples of spiked honeys $(n=11)$ were subjected to laboratory pasteurization $\left(78^{\circ} \mathrm{C} / 1 \mathrm{~min}\right)$ by introducing them in a preheated Tembloc oven, so that honey samples quickly reached the pasteurization temperature. Immediately after treatment, they were cooled at room temperature in an ice bath. Samples were then analyzed for TC residue levels.

\subsubsection{Storage study}

Spiked honey samples $(n=11)$ were divided in three 50-g subsamples, settled into a glass pot with a metal screw and stored at room temperature $\left(20^{\circ} \mathrm{C} \pm\right.$ $5^{\circ} \mathrm{C}$ ), in darkness. One 50 -g subsample was analyzed at 30,90 , and 180 days.

\subsection{Optimization of the analytical method for the determination of $\mathrm{TC}$ residues in honey}

The method is based on that described by Oka et al. (1987) and consists of four different steps: a honey sample preparation, followed by an extraction of analytes, a clean-up of the extract, and the determination of the analytes. Diverse modifications were carried out in our laboratory in order to optimize the analytical method. The following parameters were tested in our laboratory: (a) solid phases ( 0.5 and $1.0 \mathrm{~g}$ of $\mathrm{C}_{18}$, and $1 \mathrm{~g}$ of phenyl), (b) elution solvents (acetonitrile, 20:80 acetonitrile/oxalic acid, 15:85 acetonitrile/oxalic acid, ethyl acetate, 95:5 ethyl acetate/methanol, 90:10 ethyl acetate/methanol, and 80:20 acetate/methanol), and (c) elution solvent volumes $(6,10$, and $13 \mathrm{~mL}$ of 90:10 ethyl acetate/ methanol) for the SPE. For the chromatographic analysis, (a) isocratic (acetonitrile/oxalic acid in different proportions, and 1:1.5:3 methanol/acetonitrile/oxalic acid) and gradient elution (methanol/ oxalic acid and acetonitrile/oxalic acid), as well as (b) different $\mathrm{pH}(2.5,3.0$, and 3.5) of the mobile phase have been assayed.

Briefly, the optimized method was as follows. After homogenizing the sample, $3 \mathrm{~g}$ of honey were weighed and dissolved in a $6 \mathrm{~mL}$ EDTA-McIlvaine buffer ( $\mathrm{pH} 4$ ). The resultant solution was homogenized in a vibratory stirrer at $800 \mathrm{rpm}$ for $10 \mathrm{~min}$. The homogenized sample was loaded onto a column of $1 \mathrm{~g}$ of $\mathrm{C}_{18}$, previously conditioned and activated with acetonitrile $(5 \mathrm{~mL})$, oxalic acid $(\mathrm{pH} 3 ; 5 \mathrm{~mL})$, and saturated EDTA solution $(5 \mathrm{~mL})$, surrendering to a solid phase extraction. The elution solvent consisted of 90:10 ethyl acetate/methanol $(13 \mathrm{~mL})$. Eluate was concentrated under vacuum and the residue was dissolved with $1 \mathrm{~mL}$ acetonitrile-oxalic acid to pH 3 (15:85), solvents that later will be used as mobile phase in the chromatographic determination by HPLC.

Chromatographic conditions Flow mobile phase, $1 \mathrm{~mL} / \mathrm{min} ; \mathrm{C}_{18}$ column at $25^{\circ} \mathrm{C}$; wavelength, $357 \mathrm{~nm}$; time of analysis, $25 \mathrm{~min}$; mobile phase, solvent $\mathrm{A}$,

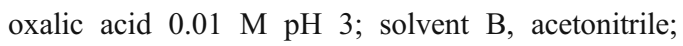
gradient elution (solvent $\mathrm{B}$ ), time $0,15 \% ; 3 \mathrm{~min}$, $12 \%$; $13 \mathrm{~min}, 20 \%$, $23 \mathrm{~min}, 25 \%$; $25 \mathrm{~min}, 15 \%$.

\subsection{Method validation}

Food and Drug Administration (FDA) criteria (FDA 2000) have been followed to validate the method, including studies of linearity, precision (repeatability and reproducibility), accuracy and sensitivity (detection limit and quantification limit). Fortified honey samples, previously analyzed for checking the absence of TC residues, were used for precision and accuracy studies. The same matrices were used as method blank, which serves to determine if analytes or any interference are present in the laboratory environment, reagents, or apparatus.

The detector's linear range has been calculated as the range of analyte weight over which the sensitivity of the detector is constant to $\pm 5.0 \%$, as determined from a linearity plot of response/weight vs. $\log$ weight. Studies of repeatability, reproducibility, and 
recovery were also carried out. The analyses were always performed in duplicate. For the repeatability study, 18 samples were spiked at $350 \mathrm{ng} / \mathrm{g}$ honey and then analyzed by the same operator, with the same equipment, in the same laboratory, on the same day. Conditions for reproducibility study were as follows: analysis of 27 samples (spiked at $350 \mathrm{ng} / \mathrm{g}$ honey), same operator, same equipment, same laboratory, three different days within 2 weeks. Finally, the recovery study ( $n=10$ samples), was carried out by spiking extracts at two concentration levels, 50 and $350 \mathrm{ng} / \mathrm{g}$, and then samples were analyzed.

Analytical sample batches were constituted by a calibration standard solution (at three levels), a method blank, a spiked sample to check the ongoing precision and recovery, and finally, a set of four to six samples to be analyzed.

The quality of analytical data was also assured by participation in international intercomparison exercises.

\subsection{Statistical analysis}

A descriptive statistical analysis was applied to the validation data. A Student's $t$ test was used to evaluate significance of differences between TC residue levels after pasteurization treatment or storage.

\section{RESULTS AND DISCUSSION}

\subsection{Optimization and validation of the analytical method}

The best results for the optimization of the method were achieved with $1.0 \mathrm{~g}$ of $\mathrm{C}_{18}$ as solid phase for SPE (recoveries of TC residues between $82 \%$ and $99 \%$ ) and $13 \mathrm{~mL}$ of $90: 10$ ethyl acetate/methanol for the elution solvent (recoveries up to $98 \%$ ). Best chromatographic conditions were $0.01 \mathrm{M}$ oxalic acid (solvent $\mathrm{A}$ ) and acetonitrile (solvent $\mathrm{B}$ ) at $\mathrm{pH} 3$ as mobile phase with the following gradient elution: Solvent $\mathrm{B}$ at time $0,15 \% ; 3 \mathrm{~min}, 12 \%$; $13 \mathrm{~min}, 20 \%$; $23 \mathrm{~min}, 25 \%$; $25 \mathrm{~min}, 15 \%$. Figure 1 shows tetracyclines 3D spectra according to the described method, in which optimal resolution can be observed.

Most researchers obtained good results using the non polar $\mathrm{C}_{18}$ solid-phase (Guo-Hui et al. 2005; Viñas et al. 2004; Pagliuca et al. 2002; Münstedt et al. 2002; Oka et al. 1994; 1993; Takeba et al. 1984). However, Nakazawa et al. (1999) used the polar solid-phase $\mathrm{ENV}^{+}$, while other researchers use a SPE column tandem (Pena et al. 2005; Geertsen and Pederson 2000;

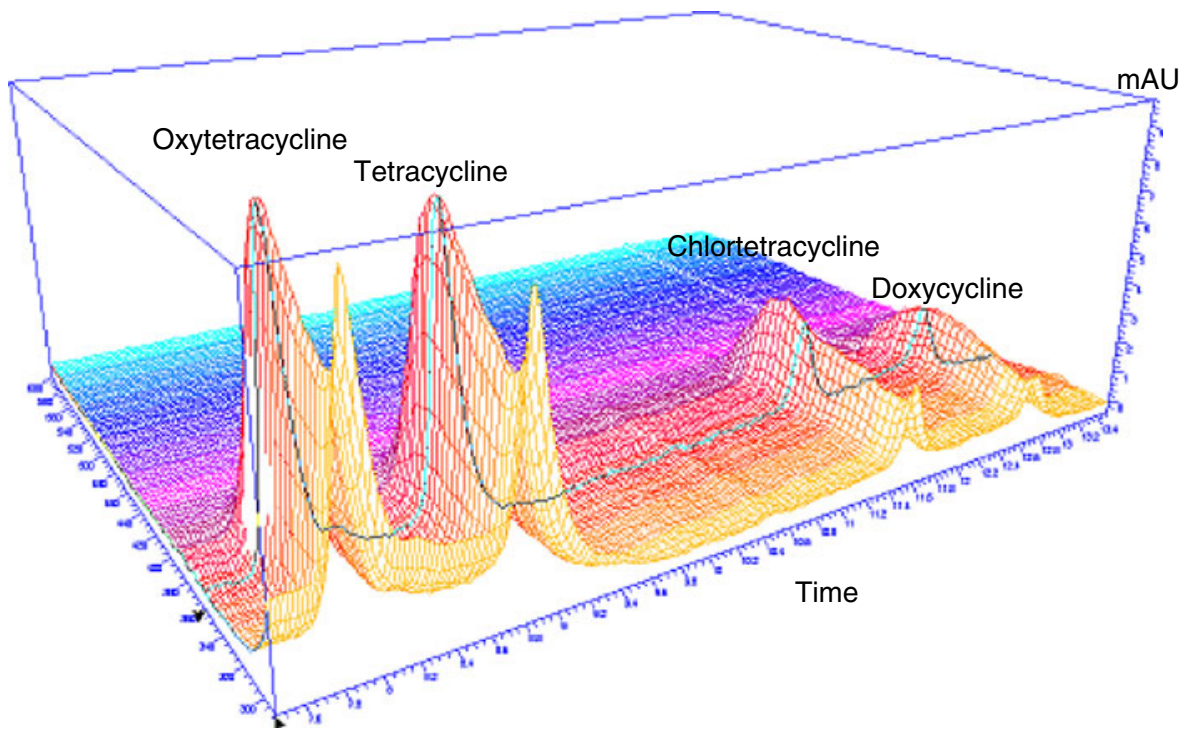

Figure 1. 3D absorption spectra of oxytetracycline, tetracycline, chlortetracycline, and doxycycline. 
Oka et al. 1987, 1994). Regarding the amount of packing material, $500 \mathrm{mg}$ cartridges are mostly used, although other authors reported the use of $60 \mathrm{mg}$ (Pena et al. 2005), $100 \mathrm{mg}$ (Oka et al. 1987), or $200 \mathrm{mg}$ of packing material (Pagliuca et al. 2002; Oka et al. 1987).

As for the elution solvent, acetonitrile, methanol, oxalic acid, water and ethyl acetate, individually or mixed, are the mostly employed, depending on the class of tetracycline analyzed and the packing material used for the SPE (Guo-Hui et al. 2005; Pena et al. 2005; Viñas et al. 2004; Pagliuca et al. 2002; Münstedt et al. 2002; Geertsen and Pederson 2000; Nakazawa et al. 1999; Oka et al. 1987, 1994; Takeba et al. 1984).

For the chromatographic analysis of tetracyclines, an acid/organic solvent solution (80:20) $\mathrm{pH} 2-4$ is commonly used as mobile phase, being methanol, acetonitrile or both on them the organic solvents chosen (Guo-Hui et al. 2005; Viñas et al. 2004; Pagliuca et al. 2002; Geertsen and Pederson 2000; Nakazawa et al. 1999; Oka et al. 1994; Jürgens 1981).

Validation results are indicated in Table I. Results of linearity obtained in our laboratory ranged between 5 and $500 \mathrm{ng} / \mathrm{g}$ honey for DC and CTC and between 5 and $700 \mathrm{ng} / \mathrm{g}$ honey for OTC and TC. Accuracy and precision results satisfy the international criteria (FDA 2000; Horwitz and Albert 1996). Recoveries obtained in spiked samples are very high for all tetracyclines (82-102\%) for both tested levels, particularly for assays carried out at $350 \mathrm{ng} / \mathrm{g}$ honey (around 100\%). This is in agreement with the FDA that accepts recovery-ranges between $80 \%$ and $110 \%$, and the current European regulations that accept $70-110 \%$ (Commission Decision 2002). Recovery results reported in literature range between $<80 \%$ (Nakazawa et al. 1999) and 81-97\% (Oka et al. 1987). Precision results, expressed as relative standard deviation (RSD), are also very good and were always less than $9 \%$, according to the recommendations of Horwitz and Albert $(1996$; RSD $<15 \%$ for the repeatability and $\mathrm{RSD}<31 \%$ for the reproducibility, respectively).

The detection and quantification limits for the four analytes were 1 and $5 \mathrm{ng} / \mathrm{g}$ honey, respectively, which indicates a good sensitivity of our method, similar to those obtained by Guo-Hui et al. (2005). Other methods reported higher detection and quantification limits (15-50 and 2472 ng/g honey, respectively; Geertsen and Pederson 2000; Münstedt et al. 2002; Pagliuca et al. 2002; Viñas et al. 2004; Pena et al. 2005).

\subsection{Study on the effect of pasteurization treatment on tetracycline residues}

Levels of antibiotic residues in honey before and after the pasteurization treatment were compared. The analysis of honey samples after pasteurization revealed a decrease of all tetracycline levels from $10 \%$ to $18 \%$. Specifically, tetracycline levels decreased from 490.73 to $441.66 \mathrm{ng} / \mathrm{g}$ honey (10.2\% of reduction) for oxytetracycline, from 493.45 to $401.18 \mathrm{ng} / \mathrm{g}$

Table I. Validation study results.

\begin{tabular}{|c|c|c|c|c|c|c|c|}
\hline & \multirow{2}{*}{$\begin{array}{l}\text { Lineal range } \\
\text { (ng/g honey) }\end{array}$} & \multirow{2}{*}{$\begin{array}{l}\text { Repeatability } \\
\text { (\% RSD) }\end{array}$} & \multirow{2}{*}{$\begin{array}{l}\text { Reproducibility } \\
(\% \text { RSD) }\end{array}$} & \multicolumn{2}{|c|}{ Recovery (\%) } & \multirow{2}{*}{$\begin{array}{l}\text { DL (ng/g } \\
\text { honey) }\end{array}$} & \multirow{2}{*}{$\begin{array}{l}\text { QL (ng/g } \\
\text { honey) }\end{array}$} \\
\hline & & & & $\begin{array}{l}50 \mathrm{ng} / \mathrm{g} \\
\text { honey }\end{array}$ & $\begin{array}{l}350 \mathrm{ng} / \mathrm{g} \\
\text { honey }\end{array}$ & & \\
\hline OTC & $5-700$ & 4.4 & 8.9 & 99.1 & 99.6 & 1 & 5 \\
\hline $\mathrm{TC}$ & $5-700$ & 6.9 & 8.4 & 98.9 & 102.4 & 1 & 5 \\
\hline CTC & $5-500$ & 7.7 & 8.4 & 95.8 & 102.2 & 1 & 5 \\
\hline $\mathrm{DC}$ & $5-500$ & 7.3 & 8.6 & 82.2 & 100.4 & 1 & 5 \\
\hline
\end{tabular}

$O T C$ oxytetracycline, $T C$ tetracycline, $C T C$ chlortetracycline, $D C$ doxycycline, $D L$ detection limit, $Q L$ quantification limit, $R S D$ relative standard deviation 
Table II. Evolution of tetracycline levels in honey during storage at $20^{\circ} \mathrm{C} \pm 5^{\circ} \mathrm{C}$ and darkness.

\begin{tabular}{lllll}
\hline Time of storage (days) & OTC (ng/g honey) & TC (ng/g honey) & CTC (ng/g honey) & DC(ng/g honey) \\
\hline 0 & 490.73 & 493.45 & 490.73 & 486.82 \\
30 & 410.45 & 391.73 & 381.55 & 386.18 \\
90 & 258.73 & 256.09 & 169.00 & 130.73 \\
180 & 85.36 & 105.00 & 71.91 & 57.09 \\
\hline
\end{tabular}

honey $(18.7 \%)$ for tetracycline, from 490.73 to $426.94 \mathrm{ng} / \mathrm{g}$ honey $(13.0 \%)$ for chlortetracycline and, finally, from 486.82 to $437.65 \mathrm{ng} / \mathrm{g}$ honey $(10.1 \%)$ for doxycycline. The statistical analysis (ANOVA test) demonstrated that these reductions were significant $(P=0.0001)$. To our knowledge, there are no similar studies in honey.

As most European countries have zero tolerances, even the low concentrations of residues detected after pasteurization (401.18$441.66 \mathrm{ng} / \mathrm{g}$ honey) cannot be accepted.

\subsection{Study on the effect of storage time in darkness on tetracycline residues}

Results of the effect of storage time on tetracycline levels are shown in Table II. A continuous decrease was observed for all tetracyclines. At day 30, a slight decrease (15-21\%) similar for all tetracyclines was observed. This trend continued after 90 days, although was most pronounced for CTC and DC, which showed reductions of $65 \%$ and $73 \%$, respectively.

After 180 days of storage, all tetracycline levels were reduced by $78-88 \%$ (Figure 2). In addition, the statistical analysis (Student's $t$ test) of results revealed that the observed reduction was significant for all tetracyclines/oxytetracycline $(P=$ 0.006), tetracycline $(P=0.0001)$, chlortetracycline $(P=0.0093)$, and doxycycline $(P=0.007)$.

Matsuka and Nakamura (1990) obtained a $50 \%$ decrease of oxytetracycline levels after 70 days in honey stored at $25^{\circ} \mathrm{C}$, and after 42 days when stored at $35^{\circ} \mathrm{C}$. Similarly, Argauer and Moats (1991) reported a 50\% decrease of oxytetracycline levels in honey after 12 days of storage at $34^{\circ} \mathrm{C}$. These earlier decreases of tetracycline levels could be attributed to the higher storage temperature.

Liang et al. (1998) investigated the stability of tetracycline on methanol solution. Tetracy-

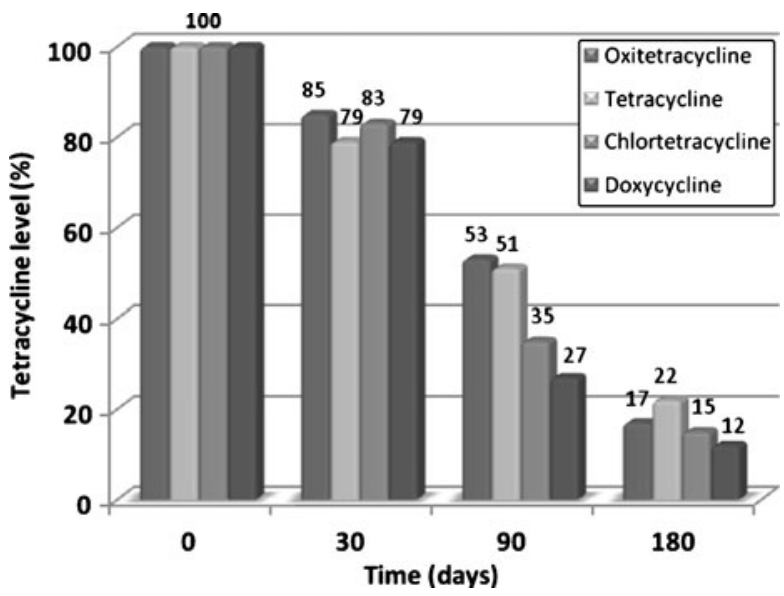

Figure 2. Evolution of TC levels in honey during storage at $20^{\circ} \mathrm{C} \pm 5^{\circ} \mathrm{C}$ and darkness. 
cline decomposed rapidly under the influence of light and atmospheric oxygen.

Tayar et al. (2010) reported residue levels of OTC, TC, and CTC were reduced 97\%, 76\%, and $71 \%$, respectively, after 60 days of storage for commercial honey samples.

\section{CONCLUSIONS}

In conclusion, we have validated a simple, fast, and sensible analytical method, according to international criteria, which could be used for routine analysis.

Pasteurization treatment and storage conditions influence the tetracycline residue levels in honey. In fact, all tetracycline levels decreased after the pasteurization, with oxytetracycline showing the largest decline. In addition, after 90 days of storage, a $50 \%$ decrease of tetracycline levels was observed, with up to $70 \%$ decrease for CTC and DC. However, it is not possible to conclude that, after pasteurization or the periods of storage used in this study, honey is free of TC health-related problems.

When conducting a risk assessment of tetracyclines in human health, the presence of these contaminants in honey and other bee products should be considered as a potential source, depending on levels of contaminants and the daily intake of honey.

In order to protect consumer health, good sanitary practices by beekeepers should be employed and monitored by technicians and public health authorities. The results of this study suggest that pasteurization and storage according to the assayed conditions do not guarantee the absence of tetracycline residues in honey.

\section{ACKNOWLEDGEMENT}

The authors wish to thank the Government of Aragón (Spain) for its financial support (Grupo de Investigación Consolidado A01/2009).

Effets de la pasteurisation et du stockage sur les teneurs en tétracyclines dans le miel. miel / tetracyclines / pasteurisation / stockage / risque sanitaire

Zusammenfassung - Der Einfluss von Pasteurisierung und Lagerung auf den Gehalt von Tetracyclinen in Honig. Tetracycline sind Antibiotika mit einem breiten Wirkungsspektrum, die das Bakterienwachstum durch eine Hemmung der Proteinsynthese verhindern. In der Imkerei haben sie sich als wirksame Mittel zur Kontrolle der amerikanischen und europäischen Faulbrut erwiesen. Allerdings kann das Auftreten von Rückständen der Tetracycline in Honig ein Risiko für die Verbraucher weltweit darstellen (allergische Reaktionen, Entwicklung resistenter Bakterienstämme, Veränderungen der Darmflora sowie mutagene und/oder karzinogene Effekte; Demoly and Romano 2005; Andersen et al. 2005). Tetracycline sind daher nicht für die Behandlung von Honigbienen in der EU zugelassen und es wurde auch kein "maximal residue level"(maximaler Rückstandswert: MLR) festgesetzt, obwohl einige Staaten auf der Basis eines Kaskadensystems Tetracyclin in die Liste der zugelassenen Produkte aufgenommen haben. Dieses Kaskadensystems erlaubt die Verwendung von Tierarzneimitteln, die in anderen Ländern zugelassen sind. Die FAO/WHO setzte im Jahr 1998 Werte für die maximale tägliche Aufnahme (acceptable daily intake, ADI) von $0-0,03 \mathrm{mg} / \mathrm{kg}$ Körpergewicht für Oxytetracyclin, Tetracyclin, und Chlortetracyclin fest. Es ist daher wichtig, dass die Nachweisemethoden für die Rückstandsanalytik von Antibiotika so empfindlich und zuverlässig wie möglich sind, um sicherzustellen, dass der in der EU vermarktete Honig die Anforderungen der EU erfüllt.

In dieser Studie wurde eine Methode für den Nachweis der Rückstände von Oxytetracyclin, Tetracyclin, Chlortetracyclin und Doxycyclin in Honig entwickelt und validiert. Dabei wurden Honigproben in EDTA-Mcllvaine-Puffer ( $\mathrm{pH}$ 4)gelöst und die homogenisierte Probe auf eine $\mathrm{C}_{18}$ Säule geladen, die zuvor mit Acetonitril, Oxalsäure $(\mathrm{pH} 3)$ und gesättigter EDTA-Lösung konditioniert und aktiviert wurde. Danach wurde die Probe nach einer Festphasenextraktion (SPE) über eine 90:10 Ethylacetat/ Methanol Lösung eluiert. Das Eluat wurde unter Vakuum konzentriert und danach in AcetonitrilOxalsäure (15:85) bei pH 3 gelöst. Diese Lösung wurden später als mobile Phasen für die HPLC-DAD verwendet. Nach der Validierung der Nachweismethode untersuchten wir die Entstehung von Tetracyclin-Rückständen in Honigen unter zwei unterschiedlichen experimentellen Bedingungen: Pas- 
teurisation im Labor $\left(78^{\circ} \mathrm{C} / 1 \mathrm{~min}\right)$ und Lagerung (Raumtemperatur/Dunkelheit über 30, 90, und 180 Tage). Die Tetracyclin-Rückstände nahmen nach der Pasteurisation um 10-19\% ab. Die TetracyclinRückstände in den gelagerten Proben nahmen um 18,5\% nach 30 Tagen, 58,5\% nach 90 Tagen und $83,5 \%$ nach 180 Tagen ab.

Zusammenfassend kann man feststellen, dass angesichts der "Nulltoleranz"in Europa (kein MLR für Tetracyclin) die Pasteurisation und die Lagerung von Honig keine Garantie dafür sind, dass so behandelte Honige danach unbelastet von Tetracyclin-Rückständen sind.

\section{Honig / Tetracycline / Pasteurisierung / Lagerung / Gesundheitsrisiko}

\section{REFERENCES}

Alfredsson, G., Branzell, C., Granelli, K., Lundström, $\AA$. (2005) Simple and rapid screening and confirmation of tetracyclines in honey and egg by a dipstick test and LC-MS/MS. Anal. Chim. Acta. 529, 47-51

Andersen, W.C., Roybal, J.E., Gonzales, S.A., Turnipseed, S.B., Pfenning, A.P., Kuck, L.R. (2005) Determination of tetracycline residues in shrimp and whole milk using liquid chromatography with ultraviolet detection and residue confirmation by mass spectrometry. Anal. Chim. Acta. 529, 145-150

Argauer, R.J., Moats, W.A. (1991) Degradation of oxytetracycline in honey as measured by fluorescence and LC assays. Apidologie 22, 109-115

Commission Decision of 12 August 2002 implementing Council Directive 96/23/EC concerning the performance of analytical methods and the interpretation of results, OJ L 221, 8-36

Committee on the Food Chain and Animal Health (2007) Summary record of the standing committee on the food chain and animal health. Section Biological Safety of the Food Chain. Section Plant Protection Products-Legislation. Brussels, 18 September

Demoly, P., Romano, A. (2005) Update on Betalactam allergy diagnosis. Curr. Allergy Asthma Rep. 1, 9-14

European Medicines Agency (2010) Report of the Workshop on medicines for bees - What the Agency can do to increase availability. EMA/28057/2010. London, 14-15 December 2009

Food and Drug Administration de EE.UU (FDA) (2000) Guideline for industry. Analytical Procedures and Methods Validation

Food Standards Agency (FSA) (2010) Testing for oxytetracycline residues in honey following treatment of bees for a European Foulbrood outbreak in Scotland. Available from: http://www.food.gov.uk/consultations/ consultni/2010/testoxytetracyclineresiduesni. Accessed 26 March 2011

Geertsen G, Pederson B (2000) Determination of residual tetracyclines in honey by HPLC-UV: Optimization and validation, in: van Ginkel LA, Ruiter A (Eds.), Proceedings of Euroresidue IV Conference, Residues of Veterinary Drugs in Foods, Veidhoven, The Netherlands, pp. 460-464

Guo-Hui, W., Cui, H., Zheng, H.S., Zhou, J., Liu, L.J., Yu, X.F. (2005) Determination of tetracyclines residues in honey using high-performance liquid chromatography with potassium permanganatesodium sulfite- $\beta$-cyclodextrin chemiluminescence detection. J. Chromatogr. B. 824, 57-64

Hammel, Y.A., Mohamed, R., Gremaud, E., LeBreton, M.H., Guy, P.A. (2008) Multi-screening approach to monitor and quantify 42 antibiotic residues in honey by liquid chromatography-tandem mass spectrometry. J. Chromatogr. A. 1177, 58-76

Heering, W., Usleber, E., Dietrich, R., Martlbauer, E. (1998) Immunochemical screening for antimicrobial drug residues in commercial honey. Analyst 123, 2759-2762

Horwitz, W., Albert, R. (1996) Reliability of the determination of polychlorinated contaminants (biphenyls, dioxins, furans). J. AOAC International 77, 79-86

Huq, S., Garriques, M., Kallury, K.M.R. (2006) Role of zwitterionic structures in the solid-phase extraction based method development for clean up of tetracycline and oxytetracycline from honey. J. Chromatogr. A. 1135, 12-18

Jeon, M., Paeng, I.R. (2008) Quantitative detection of tetracycline residues in honey by a simple sensitive immunoassay. Anal. Chim. Acta. 626, 180-185

Jinbo, K., Monma, C., Matsumoto, M., Maruyama, T. (1992) Simplified detection method for residual tetracyclines and sulfa drugs in honey by microbiological assay. Ann. Rep. Tokyo Metr. Res. Lab. P. H. 33, 217-222

Jürgens, U. (1981) Zur hochdruckflüssig chromatographschen Analyse von Arzneimittelrückständen in Honig. Z. Lebensm. Unters. Forsch. 173, 356-358

Kaczmarek, M., Lis, S. (2009) Chemiluminescence determination of tetracyclines using Fenton system in the presence europium (III) ions. Anal. Chim. Acta. 639, 96-100

Levy, S.B. (1992) The antibiotic paradox: how miracle drugs are destroying the miracle. NY, Plenum Press, New York

Li, J., Chen, L., Wang, X., Jin, H., Ding, L., Zhang, K., Zhang, H. (2008) Determination of tetracyclines residues in honey by on-line solid-phase extraction high-performance liquid chromatography. Talanta 75, 1245-1252

Liang, Y., Denton, M.B., Bates, R. (1998) Stability studies of tetracycline in methanol solution. J. Chromatogr. A. 827, 45-55 
López, M.I., Pettis, J.S., Smith, I.B., Chu, P.S. (2008) Multiclass determination and confirmation of antibiotic residues in honey using LC-MS/MS. J. Agric. Food Chem. 56, 1553-1559

Matsuka, M., Nakamura, H. (1990) Oxytetracycline residues in honey and royal jelly. J. Apic. Res. 29, 112-117

Münstedt T, Rademacher E, Petz M (2002) HPLC, Charm II and ELISA: advantages and disadvantages for the analysis of tetracyclines in honey, International Symposium APIMONDIA. Preventing Residues in Honey, Celle, 10-11. www.apiservices.com/apimondia

Nakazawa, H., Ino, S., Kato, K., Watanabe, T., Ito, Y., Oka, H. (1999) Simultaneous determination of residual tetracyclines in foods by high-performance liquid chromatography with atmospheric pressure chemical ionization tandem mass spectrometry. J. Chromatogr. B. 732, 173-180

National Association of Consumers and Users (OCU) (2003) Antibióticos en alimentos. Un verdadero problema. OCU-SALUD 46, 14-17

Oka, H., Ikai, Y., Kawamura, N., Uno, K., Yamada, M. (1987) Simultaneous analysis of seven tetracyclines in honey. J. Chromatogr. 400, 253-261

Oka, H., Ikai, Y., Hayakawa, J., Harada, K., Masuda, K., Suzuki, M., Himei, R., Morie, M., Nakazawa, H. (1993) Identification of residual tetracyclines in honey by TLC/ FABMS. J. Food Hygiene Soc. Jpn. 34, 517-523

Oka, H., Ikai, Y., Hayakawa, J., Harada, K., Asukabe, H., Suzuki, M., Himei, R., Horie, M., Nakazawa, H., McNeil, J. (1994) Improvent of chemical analysis of antibiotics. identification of residual tetracycline in honey by frit $\mathrm{FAB} / \mathrm{LC} / \mathrm{MS}$ using a volatile mobile phase. J. Agric. Food Chem. 42, 2215-2219

Pagliuca, G., Gazzotti, T., Serra, G., Sabatini, A. (2002) A scientific note on the determination of oxytetracycline residues in honey by HPLC-UV detection. Apidologie 33, 583-584

Pancorbo, A.C., Terrones, S.C., Carretero, A.S., Gutiérrez, A.F. (2008) Reversed-phase high performance liquid chromatography coupled to ultraviolet and electrospray time of-flight mass spectrometry on-line detection for the separation of eight tetracyclines in honey samples. J. Chromatogr. A. 1195, 107-116

Pastor-Navarro, N., Morais, S., Maquieira, A., Puchades, R. (2007) Synthesis of haptens and development of a sensitive immunoassay for tetracycline residues: application to honey samples. Anal. Chim. Acta. 594, 211-218

Pena, A., Palilis, L.P., Lino, C.M., Silveira, M.I., Calokerinos, A.C. (2000) Determination of tetracy- cline and its major degradation products by chemiluminescence. Anal. Chim. Acta. 405(1-2), 51-56

Pena, A., Pelantova, N., Lino, C., Silveira, M., Solich, P. (2005) Validation of an analytical methodology for determination of oxytetracycline and tetracycline residues in honey by HPLC-FLD. J. Agric. Food Chem. 53, 3784-3788

Regulation (EU) No 37/2010 on pharmacologically active substances and their classification regarding maximum residue limits in foodstuffs of animal origin

Regulation (EC) No 470/2009 of the European Parliament and of the Council of 6 May 2009 laying down Community procedures for the establishment of residue limits of pharmacologically active substances in foodstuffs of animal origin, repealing Council Regulation (EEC) No 2377/90 and amending Directive 2001/82/EC of the European Parliament and of the Council and Regulation (EC) No 726/2004 of the European Parliament and of the Council, OJ L152, 16.6.2009, p. 11-22

Reybroeck, W. (2003) Residues of antibiotics and sulphonamides in honey on the Belgian market. APIACTA 38, 23-30

Reybroeck, W., Ooghe, S., De Brabander, H.F., Daeseleire, E. (2007) Validation of the Tetrasensor honey test kit for the screening of tetracyclines in honey. J. Agric. Food Chem. 55, 8359-8366

Sabatini, A.G., Carpara, E., Serra, G., Colombo, R. (2003) Presence of acaricides and antibiotics in samples of Italian honey. APIACTA 38, 46-49

Salinas, F., Espinosa, M.A., Berzas Nevado, J.J. (1991) Simultaneous determination of sulfathiazole and oxytetracycline in honey by derivative spectrophotometry. Microchem. J. 43, 244-252

Sun, X., He, X., Zhang, Y., Chen, L. (2009) Determination of tetracyclines in food samples by molecularly imprinted monolithic column coupling with high performance liquid chromatography. Talanta 79, 926-934

Takeba, K., Kanzaki, M., Murakami, F., Matsumoto, M. (1984) Simplified analytical method for tetracyclines residues in honey by HPLC. Ann. Rep. Tokyo Metr. Res. Lab. P.H. 35, 187-191

Tayar, G., Rath, S., Guillermo, F., Reyes, R. (2010) A HPLC with fluorescence detection method for the determinationof tetracyclines residues and evaluation of their stability in honey. Food Control 21, 620-625

Viñas, P., Balsalobre, N., López-Herroz, H., HernándezCórdoba, M. (2004) LC with ultraviolet absorbance detection for the analysis of tetracycline residues in honey. J. Chromatogr. A. 1022, 125-129 